\title{
Efficiency and System in Municipal Services: Fire Departments in Iowa, 1870-1890.
}

\section{Maureen Ogle}

BEFORE 1870, when a fire broke out in an Iowa city, townspeople hurried to the scene. Some citizens arranged themselves in bucket brigades stretching from the fire to the nearest well or cistern. Others worked quickly to remove goods from nearby buildings threatened by the fire. But beyond the crowds that gathered to fight fires, little existed in the way of formally organized fire-fighting services. In the 1870s and 1880s, however, residents of Iowa's cities sought to develop more efficient ways of fighting fires. Abandoning the ad hoc basis of the bucket brigades, they organized and equipped specially designated people for the task. ${ }^{1}$

Little is known about the history of fire fighting in the hundreds of small cities that dot the American landscape. Those scholars who have explored the nature of this important urban service have focused on a few of the nation's largest cities in the antebellum era. Too often, the histories of a few specific big city fire departments have been accepted as the history of American fire fighting in general.

According to one standard interpretation of the emergence of urban fire departments, "rowdyism" reigned supreme in the

I would like to thank Professor William S. Robinson for his careful reading of and comments on this essay.

1. The best documentation for nineteenth-century fire-fighting procedures can be found in scenes portrayed in paintings and etchings of the period. Reproductions of such works can be found in Paul C. Ditzel, Fire Engines, Firefighters (New York, 1976), and M. J. McCosker, The Historical Collection of the Insurance Company of North America (Philadelphia, 1945).

THE ANNALS OF IOWA 50 (Spring 1991). CThe State Historical Society of Iowa, 1991. 
ranks of volunteer fire fighters during the 1840 s and $1850 \mathrm{~s}$. The brawling, squabbling, and drunken revelry of the unruly young men who dominated the ranks of volunteer fire companies left the rest of the citizenry helpless in the face of conflagration. ${ }^{2}$ Moreover, these urban outlaws were to a certain extent beyond the law, since residents feared that the men might refuse to fight fires on the properties of those who opposed their antics. In an effort to rectify this situation and better control fire fighters, the argument continues, a few cities instituted full-time, paid fire departments: Cincinnati in 1853, St. Louis and Louisville in 1857. From these studies of unruly volunteers, some historians have concluded that the emergence of "modern" fire-fighting service in America starts with rowdyism at mid-century, and leads directly to paid fire departments shortly thereafter. $^{3}$

Other historians studying American fire fighting have focused on the introduction of the steam fire engine, and a general desire to bring order to otherwise chaotic collections of separate volunteer fire companies. These scholars have argued that in several large American cities, citizens became dissatisfied with the volunteer system; firemen, they claimed, were too disorganized, unreliable, inefficient, and prone to infighting to meet the growing cities' needs. Desiring more rational fire-fighting services, cities such as Pittsburgh, New York, and Boston replaced volunteers with troops of paid, "professional," full-time firemen using such modern equipment as steam fire engines to fight fires. In this case, then, the

2. The use of male nouns and pronouns is intentional; there were no women involved in the development of the fire-fighting institutions described here.

3. For research that ties "rowdyism" directly to the emergence of paid fire departments, see Arlen R. Dykstra, "Rowdyism and Rivalism in the St. Louis Fire Department, 1850-1857," Missouri Historical Review 69 (197475), 48-64; John B. Clark, Jr., "From Bucket Brigade to Steam Fire Engine Fire Fighting in Old Louisville through 1865," Filson Club History Quarterly 27 (1953), 103-18; George D. Bushnell, "Chicago's Rowdy Fire Fighters," Chicago History 2 (1973), 232-41; Geoffrey Giglierano, "'A Creature of Law': Cincinnati's Paid Fire Department," Cincinnati Historical Society Bulletin 40 (1982), 79-99; Ernest S. Griffith and Charles R. Adrian, A History of American City Government: The Formation of Traditions, 1775-1870 (1976; reprint ed., Washington, DC, 1983), 95-96. A more recent and provocative interpretation is in Eric H. Monkkonen, America Becomes Urban: The Development of U.S. Cities and Towns, 1780-1980 (Berkeley, CA, 1988), 105-8. 
argument focuses not on rowdy firemen, but on a perceived need to improve the organization of existing fire-fighting services. ${ }^{4}$

These analyses have merit for the times and places they were designed to explain, but they offer little help for understanding the emergence of fire departments in the small cities of Iowa and elsewhere. They describe the events leading up to the creation of paid, "professional" fire departments in a few large cities, but tell us almost nothing about the management and organization of the hundreds of volunteer fire companies and departments that provided services in those smaller cities. And because of the focus on a few large cities, most research into fire fighting has concentrated on the mid-century years, from about 1840 to 1860 . But for the peak years of urban growth in this country-the closing decades of the nineteenth century - we know little about the ways in which urban Americans organized fire fighting. ${ }^{5}$

This essay fills some of those gaps by examining the changing nature of fire fighting between 1870 and 1890 in three Iowa cities: Boone, Iowa City, and Marshalltown. All three cities were small; by 1895 only Marshalltown had passed the ten thousand

4. See Ronald M. Zarychta, "Municipal Reorganization: The Pittsburgh Fire Department as a Case Study," Western Pennsylvania Historical Magazine 58 (1975), 471-86; Richard B. Calhoun, "New York City Fire Department Reorganization, 1865-1870: A Civil War Legacy," New-York Historical Society Quarterly 60 (1976), 7-34; James Boyd Jones, Jr., "Mose the Bowery B'hoy and the Nashville Volunteer Fire Department, 1849-1860," Tennessee Historical Quarterly 40 (1981), 170-81; idem, "The Memphis Firefighters' Strikes, 1858 and 1860," East Tennessee Historical Society's Publications 49 (1977), 37-60.

5. The antebellum era has received most of the attention from historians studying fire fighting. Besides the essays listed previously-most of which focus on the antebellum years-see also Carey Hearn, "Fire Control in Antebellum Mississippi," Journal of Mississippi History 40 (1978), 319-27; Kathleen J. Kiefer, "Flying Sparks and Hooves: Prologue," Cincinnati Historical Society Bulletin 28 (1970), 83-107; A. B. Lampe, "St. Louis Volunteer Fire Department, 1820-1850: A Study in the Volunteer Age," Missouri Historical Review 62 (1968), 235-59; Glen E. Holt, "Volunteer Fire Fighting in St. Louis, 1818-1859," Gateway Heritage 4 (Winter 1983-84), 2-13; Stephen F. Ginsberg, "Above the Law: Volunteer Firemen in New York City, 1836-1837," New York History 50 (1969), 165-86; Bruce Laurie, "Fire Companies and Gangs in Southwark: The 1840s," in Allen F. Davis and Mark H. Haller, eds., The Peoples of Philadelphia: A History of Ethnic Groups and Lower-Class Life, 1790-1940 (Philadelphia, 1973), 71-87. 
mark. ${ }^{6}$ None of the three cities established paid, full-time fire departments during those years, nor were they trying to reform existing volunteer companies. Instead, these three cities strove to achieve efficiency in a vital municipal service. That desire for efficiency shaped the organization of the tools of fire fighting as well as the social relations surrounding those tools.

AN 1858 IOWA LAW allowed cities of the second class (those with populations of two to fifteen thousand) to organize companies of volunteer firemen. In practice that meant residents organized fire companies, and the city council sanctioned the companies' bylaws and constitutions and granted the firemen minimal police powers over citizens at the scene of a fire. Iowa City had enjoyed this power since the 1850s; the other two gained it when they became second-class cities in the late sixties. Iowa City's city council had, after much debate, actually passed an "Ordinance to establish Fire Companies in Iowa City" in 1861, and grudgingly paid for some equipment. With one short-lived exception, however, the citizens of Iowa City did not organize any companies until the early 1870 s, nor did they maintain or add to the existing equipment. The Boone and Marshalltown city councils and citizens neither encouraged nor supported any kind of fire-fighting services before 1870, even after they had achieved second-class status. Thus, until 1870 bucket brigades continued to serve as the main tool for fighting fires in these cities.?

6. For information on the three cities, see N. E. Goldthwait, History of Boone County, Iowa (Chicago, 1914); History of Johnson County, Iowa (Iowa City, 1883); and Judge William Battin and F. A. Moscrip, Past and Present of Marshall County, Iowa (Indianapolis, 1912). Populations in 1875 were Boone, 2,415; lowa City, 5,914; and Marshalltown, 3,218. By 1895 the numbers were Boone, 8,845; Iowa City, 7,526; and Marshalltown, 10,049. Population data taken from Census of lowa for 1895.

7. For Iowa City, see Minutes of the lowa City City Council, 21 November 1859, 2 January, 10, 17 November 1860, 29 March, 24 May, 13 October 1861, 11 January 1862 (hereafter cited as Minutes-Iowa City). A brief discussion of an early Iowa City fire company is in Carl B. Cone, "The Iowa Firemen's Association," Iowa Journal of History and Politics 42 (1944), 228. There is no mention of any fire companies or fire company expenses in the Marshalltown city council minutes prior to 1868 , and none at all in Boone minutes for the entire decade. Newspaper descriptions of the paucity of fire protection in Marshalltown are in Marshall County Times, 14 November 1866, 7 March, 30 May 1868. 
Fire prevention played a part in the cities' fire services. The Iowa Code allowed city councils to appoint "fire wardens" who examined residential and business chimneys, flues, and hearths. Municipalities also established "fire limits" upon petition of two-thirds of the property owners in a block. Typically these ordinances prohibited the stacking of hay within the area, mandated the size and materials to be used in the construction of chimneys and stove pipes, and dictated that new buildings or additions be constructed of "non-combustible" materials. By 1870 fire limits existed in the "business areas" of all three cities. Finally, the three municipalities occasionally appointed night watchmen to patrol the streets during the winter and summer months. Their availability usually depended upon townspeople raising enough money to pay their salaries. The most these appointees could do, however, was raise the alarm and wait for others to show up, buckets in hand. ${ }^{8}$

Thus, during the 1860 s fire prevention was minimal, and fire fighting centered on ad hoc groups using a minimum of equipment, rather than on groups of formally organized fire fighters. Beginning at the end of the decade, however, and with increased momentum in the 1870 s and 1880 s, all three cities altered their fire-fighting services; that is, all three began using new combinations of people and equipment to fight fires. Acting through city councils and private fund-raising efforts, they purchased fire-fighting gear, such as hand engines, hose, and

8. For a brief discussion of early Iowa fire legislation, see Roy E. Brown, "Municipal Administration of Public Safety," in Benjamin F. Shambaugh, ed., Municipal Government and Administration in lowa, 2 vols. (Iowa City, 1930), 2:282-87; and idem, "Organization and Administration of Fire Departments in Iowa" (Ph.D. diss., University of Iowa, 1929), esp. 59-63. For ordinances, see An ordinance relating to Fire Wardens, March 1854, in Charter and Laws of Iowa City, Passed 1853, 1854, 1855, 1856. In Boone (Montana) the marshall doubled as fire warden. For fire limits, see An Ordinance for the prevention of fires or conflagrations, Montana Standard, 14 November 1868; An ordinance prohibiting the erection of wooden buildings in Block No. 80 in Iowa City, 9 September 1867; An ordinance prohibiting the erection of wooden buildings in block No. 81 in Iowa City, 3 April 1869, Revised Ordinances of 1870 of Iowa City. Concerning flues and stove pipes, see Marshalltown City Council Minutes, 2 September 1863, 19 February 1868 (hereafter cited as Minutes-Marshalltown); and An Ordinance prescribing the use of Fire and Combustible Material; the Construction of Chimney Flues; the Sale of Gunpowder, etc., Marshalltown Ordinance Record No. 1, 123. 
ladders, and organized numerous task-specific companies into fire departments. This arrangement of people and tools in formal organizations resulted in efficient, permanent, fire-fighting services in the three cities.

For example, when Marshalltown achieved second-class status in early 1868, the city council wasted little time in taking advantage of its new powers, appointing a committee to investigate "some feasable [sic] plan for the extinguishment [sic] of fires." After "making inquiries" in "Chicago and other cities," the group reported that a steam engine and "apparatus" "suitable for a city of this size" would cost ten thousand dollars. The committee recommended that the issue be presented to the voters. Voters rejected the proposal, a defeat one newspaper attributed to the lack of sufficient water to supply an engine. ${ }^{9}$ After a fire in September 1869 destroyed four buildings in the business district, however, one local newspaper pleaded with council to create a fire-fighting organization, one with "an efficient head" to assume control at fires and to direct "paralyzed citizens." At the recent fire, complained the paper, people stood by "not knowing what to do or how to do it," and it was impossible to move them toward "anything like an organized effort." Two months later, after another minor fire, the paper again pleaded for a "fire king, whose word shall be law at fires." 10

As these pleas indicate, the issue was not one of equipment so much as organization. In the closing days of 1869 the council finally passed an ordinance creating a fire department composed of separate volunteer fire companies. A designated fire chief would exercise "supreme control and command" over the fire fighters; moreover, the act spelled out a chain of command by which orders were sent from the chief, directing the action

9. Minutes-Marshalltown, 1 September, 16 November 1868; Marshall County Times, 5 December 1868. Space does not permit a full discussion of the subject of water supply and fire fighting in the three cities. A detailed discussion of the creation and management of municipal water supplies for fire and other purposes is in Maureen Ogle, "Urban Growth in Iowa: Defining and Creating the Small City, 1870-1890" (Master's research essay, lowa State University, 1988); and idem, "Redefining 'Public' Water Supplies, 18701890: A Study of Three Iowa Cities," Annals of Iowa 50 (Summer 1990), 507-30.

10. Marshall County Times, 11 September, 11 November 1869. 
through a "speaking trumpet," to the company foremen, down to the rank and file. While at the fire every fire fighter and department officer, as well as the mayor and city council members, were to wear hats, labels, and badges designating their title or position. ${ }^{11}$

This brief sketch of events indicates that the council acted to guarantee efficiency and coordination among any subsequently organized volunteers. The ordinance's strength lay in its assertion of authority and establishment of a distinct hierarchy of command. It ensured the coordination of efforts by companies when they were actually engaged in the act of fighting fires. Without the ordinance's stipulations, each volunteer company would be free to carry on as it wished at the scene of a fire, thereby decreasing the effectiveness of the fire fighters' efforts. With the ordinance, the companies' labors would be coordinated and directed, and thus more efficient. The fire department provided an alternative to the haphazard bucket brigade, bringing order and routine to the task of fire fighting. The departmental structure dictated by the ordinance duplicated the structures found in larger American cities, but there is no evidence that the council acted in response to rowdy fire fighters or problems with previously organized companies. Indeed, as near as can be determined from contemporary newspaper accounts, at the time of the ordinance's passage Marshalltown had no volunteer companies and no fire-fighting equipment. Using their new powers as a second-class city, officials moved to rectify that lack by laying the foundation for a service that resembled those in other cities, but their motivation was not one traditionally cited to explain the formation of fire departments. ${ }^{12}$

Local residents wasted little time in acting upon the new law. In mid-1870 the city council directed its newly created Committee on Fire to buy "necessary apparatus," including company uniforms, buckets, and ladders, for a recently established hook-and-ladder company. In addition, the council

11. An Ordinance establishing a Fire Department, Marshalltown Ordinance Record No. 1, 134; Minutes-Marshalltown, 20 September 1869.

12. Descriptions of similarly organized departments are in Giglierano, "A Creature of Law,'" 87, 91; Clark, "From Bucket Brigade to Steam Fire Engine," 113-14; and Jones, "The Memphis Firefighters' Strikes," 46. 
corresponded with various manufacturing companies and other cities as it contemplated the acquisition of other pieces of equipment, including a used hand engine being sold by the city of Dubuque and a chemically-based "Babcock Extinguisher." The fire extinguisher would have cost more than two thousand dollars, so the council arranged for a company representative to bring the machine to Marshalltown for a test before spending the money. ${ }^{13}$

When a fire nearly destroyed the city's business district in October 1872, however, the council concluded that despite its merits, a Babcock Extinguisher was no match for a major conflagration, and voted against buying the machine. Instead, a council committee traveled to Peoria, Illinois, to study that city's steam fire engine and municipal waterworks. The city clerk also contacted several suppliers of fire and water apparatus for information and prices. Although the council decided against the steam engine-an expensive acquisition that would have required a full-time caretaker-by early 1873 the city had a hand engine, a hook-and-ladder truck, hose, and two companies to operate the equipment. ${ }^{14}$

Events followed a similar pattern in Iowa City, even though it was the oldest and largest of the three municipalities and might have been expected to have altered its fire service earlier. In the early 1870 s Iowa Citians, expressing discontent with available fire protection-one hand engine and one engine company-began efforts to provide better service. Shortly after the 1871 Chicago fire, for example, a local news-

13. Minutes-Marshalltown, 13 June, 11 July 1870, 9 January, 14 August, 17 September, 13 November 1871, 8 January, 12 February 1872. The Babcock, a portable fire extinguisher, was described by the Scientific American 26 (1872), 56 , as "among the best of modern appliances" for fighting fire. It consisted of several tanks holding separate solutions of "liquid acid," bicarbonate of soda, and water. When the outfit was needed, the user pulled a stopper to mix the acid and soda, "in which no fire [could] live." The mixture, stored under pressure, then entered the water tank, and from there traveled under pressure though a hose. This "most scientific combination" allowed the gas to douse the flame and the water to cool the burned material. See also Ditzel, Fire Engines, Firefighters, 152, 155.

14. Minutes-Marshalltown, 7, 20, 27 May, 10 June, 8 July, 19 August, 14, 21 October 1872, 7 February 1873. For descriptions of the fire, see Battin and Moscrip, Past and Present of Marshall County, Iowa, 423-26. 
paper scornfully labeled the engine company and its equipment a mere "Bucket Brigade," insufficient to protect the city's needs should fire strike. In early 1872 , when fire destroyed a large hotel, another newspaper derided the city's ability to cope with fire. As the hotel burned, it reported, the crowd could do nothing. "There was no fire apparatus, no water, no nothing, and the people could only fold their arms and watch the devouring element." The paper berated the city council for its "misdirected efforts" that failed to meet the need for "useful and necessary" fire equipment. As had been the case in Marshalltown a few years earlier, this newspaper charged council with the responsibility of providing Iowa Citians with efficient fire protection in the form of special equipment that would, presumably, enable existing companies to work more efficiently and effectively. ${ }^{15}$

The council responded by spending five hundred dollars for hook-and-ladder equipment and buckets, and a newly organized volunteer fire company took responsibility for the gear. A year later the council investigated the purchase of more equipment by corresponding with thirty other cities, culling information on the kinds of fire apparatus they used. As a result, it decided to invest in another hand pumper rather than a more expensive steam engine. The arrival of the new equipment prompted the formation of yet another fire company. Iowa City, noted one newspaper, was finally "waking up to the importance of having an efficient Fire Department."16

The multiplication of companies prompted a new ordinance establishing a fire department. As in Marshalltown, however, passage of the ordinance did not stem from any widespread dissatisfaction with existing fire companies. Indeed, local newspapers had nothing but praise for fire fighters. Instead, it appears that the ordinance was seen more as a logical next step in the creation of an "efficient" fire-fighting service. More specific than the little-used 1861 ordinance, the new Iowa City regulation provided for companies of fire wardens and

15. Iowa City Republican, 1 November, 13 December 1871; Iowa City Daily Press, 19 March 1872.

16. Iowa City Daily Press, 2, 24, May 1872, 31 May, 7 June 1873; Iowa City Republican, 5 June 1872. 
hosemen, as well as engine and ladder men. It recognized the autonomy of these separate, task-specific companies, but defined them as a department under the supervision of a chief engineer and two assistants. Like Marshalltown's 1869 ordinance, this one also placed all the apparatus in the care of the chief and dictated that he make regular quarterly reports to the city council on the condition of the department. After a particularly bad bout of fires during the summer of 1874 , one resident, in a letter to a local newspaper, suggested that the city double the number of firemen, remarking that the only "proper way" to fight fires was with a large "disciplined" force of men supervised by a "competent head" rather than with masses of unorganized spectators. Clearly the general conception of what constituted adequate fire services had changed dramatically since the early 1860s; Iowa Citians now valued discipline, efficiency, and formal organization in their fire-fighting service. ${ }^{17}$

A slightly different chain of events unfolded in Boone during the decade. In 1870 the city council voted to buy a ladder, hooks, and ropes "for the City's use in extinguishing fires," and appointed a special committee to "experiment" with the Babcock "Fire Annihilator," a smaller version of the Babcock Extinguisher. The committee gave the Annihilator a favorable review, and the council voted to spend $\$ 450$ on ten of them. By 1871 the council was ready to expand the city's available firefighting equipment by purchasing a larger wheel-mounted Babcock Extinguisher. A special council committee traveled to Marshalltown to confer with city leaders there on the subject, but after that city's disastrous fire, Boone, too, rejected the Babcock Extinguisher. One newspaper labeled it a "squirt gun," capable only of extinguishing "incipient fires." Instead, council purchased the J. Hunt Company's "Our Favorite Model," a hook-and-ladder truck with "all necessary equipment." ${ }^{\text {"18 }}$

17. An Ordinance for the formation and government of the Fire Department, Revised Ordinances of 1874 of Iowa City; Iowa City Daily Press, 28 July 1874.

18. Minutes-Boone, 25 May, 17 August, 16 September 1870, 12 April 1871, 24 July 1872, 1, 12 February, 26 March 1873; Boone County Democrat, 1 November 1871, 14 February, 22 May 1872, 12 February, 26 March 1873; Boone County Advocate, 4 January, 21 November 1872; Boone Standard, 17 February, 11 May 1872. 
By March 1873 the equipment had arrived, and citizens, acting in accord with a recently passed ordinance, organized themselves into Boone's first volunteer fire company, the Daniel Boone Hook and Ladder Co. No. 1. Unlike the Iowa City and Marshalltown laws, Boone's ordinance provided only for a single company rather than a department. The absence of a fire department did not stop Boone residents from establishing other companies and buying equipment, however. ${ }^{19}$

In 1877 the Boone city council finally passed an ordinance creating a fire department. The debates leading to that action and its implementation reveal much about the growing emphasis on efficiency and organization in municipal fire fighting, and especially about the way townspeople perceived the role of a fire department, as opposed to fire companies.

In 1875 one editor complained that, despite the existence of two fire companies and a great deal of equipment, Boone had no "regularly organized" fire service. That is, without a department, headed by a "chief," the fire companies were not united or coordinated in their efforts. Nor were all the distinct. tasks necessary for fighting fire being handled by separate companies: the city had installed a tiny water main and one hydrant for fire protection for the main business block, and the council had bought some hose, but no one had yet organized a hose company to manage the equipment. ${ }^{20}$

Eventually, a group of residents formed a hose company, and in early 1877 the council passed a fire department ordinance. The new law endorsed the creation of different companies-hosemen, enginemen, and ladder men-and placed them under the "sole and absolute command" of a chief. In addition, it mandated that all fire wardens, wearing special badges designating their office, act as special police at fires, presumably in order to supervise the removal of goods from burning buildings. ${ }^{21}$

As was the case in Marshalltown earlier, some time passed before local fire fighters actually implemented the act. In the

19. Minutes-Boone, 12, 19 March 1873; Ordinance Record No. 1, 135-36.

20. Boone County Democrat, 3 March 1875, 17 September 1873, 14 July 1875; Minutes-Boone, 16 December 1874, 15 March 1875.

21. An Ordinance for the formation and government of the Fire Department, Ordinance Book No. 2, 45-49. 
interim one Boone newspaper lamented the disorganized and inefficient work of the city's fire fighters; after another fire the paper noted that while the companies exhibited plenty of willingness, "no one seemed to have a very clear conception of the method by which fire could best be put out." Not until August did the companies finally organize themselves "regularly" by electing a departmental chief and assistants, as dictated by the February ordinance. ${ }^{22}$

In Boone, then, it appears at first glance that passage of a fire department ordinance did in fact stem from dissatisfaction with existing methods of fire fighting. However, complaints about the way firemen conducted themselves centered not on the men themselves or their characters, ethnic background, or unruly behavior, but rather on a perceived lack of "regular" organization. A "regularly" organized fire service was one organized into a department and supervised by a chief. The issue, then, was not how to control unruly firemen, but rather how to achieve a normal, "regular" state of affairs. A city, it seemed, should have a fire department, paid or not, rather than simply a collection of volunteer companies. In that sense, then, the situation in Boone closely parallels that in some of the nation's largest cities; the Iowa case departs from the big cities, however, because the result was not a paid, full-time fire department, but the continuation of a volunteer service, organized in a particular way in order to achieve a particular end, namely systematic fire fighting. ${ }^{23}$

For these Iowans, then, the conception of an adequate firefighting service had changed since the 1860 s. Task-specific volunteer companies had replaced the ad hoc human chains that had fought earlier fires, and a collection of task-specific hardware-hand engines, ladders, and hose-had taken the place of the bucket. But the existence of companies and equipment did not in and of itself constitute proper organization. That came from the arrangement of the companies and tools in a

22. Boone County Republican, 14 March, 6, 27 June 1877; Minutes-Boone, 27 June, 1 August 1877.

23. A discussion of the trend of small cities to equip themselves with what were seen as the proper accoutrements of urban life in order to become more "citylike" is in Ogle, "Urban Growth in Iowa," chaps. 1 and 4. 
formally organized department, a system of hierarchically arranged parts that worked together in a coordinated manner. Neither the idea of a fire department nor the tools these Iowa fire fighters used were especially new; indeed, all were used in larger American cities. What differentiated the cases of Boone, Iowa City, and Marshalltown from big city fire departments organized earlier was the desire to achieve efficiency and order in this important urban service rather than the need to control groups of rowdy fire fighters. By 1880 all three cities had volunteer fire departments that in most respects-pay being the major difference-resembled the kinds of departments created earlier in other cities in response to a particular problem. The end was the same; the motivation was different. ${ }^{24}$

ALL THREE MUNICIPALITIES continued to expand and "perfect" their fire systems. Task-specific fire companies organized into departments continued to provide the foundation for fire service, but increased fire protection did not depend solely on greater numbers of people. Rather, throughout the rest of the $1870 \mathrm{~s}$ the companies accumulated more fire-fighting equipment. Besides the acquisition of ladders, engines, and trucks, each city made dozens of other purchases throughout the rest of the $1870 \mathrm{~s}$ and into the $1880 \mathrm{~s}$. For example, all three municipalities accumulated smaller pieces of equipment, such as additional hose, hose couplings, hydrant wrenches, hosedrying racks, and the like. In addition, the companies bought such things as uniforms and badges, rubber boots and coats, leather caps, lanterns, and ropes.

During the 1870s the money for these supplies came from funds provided by city councils and from the companies themselves, especially in Boone and Iowa City. The firemen's ball was more than just a social event; it fulfilled an important fundraising function. In addition, townspeople also contributed money for purchases via the ubiquitous "subscription." In Iowa

24. Some historians point to the use of steam engines as a way to control volunteers, by forcing the issue of a paid, full-time department. See note 4 above. On that point, too, the case of these three cities differs: by the late 1880 s, Iowa City and Marshalltown were using steam engines, yet there was no move to pay the fire fighters. The city councils solved the problem of engine maintenance by paying a "caretaker" to prepare and haul the engine to fires. 
City and Boone, in fact, the subscription paid for a substantial amount of the initial fire-fighting equipment, including the hook-and-ladder gear, the engine, and the first hose carts. Often the city councils in the two municipalities also appropriated funds, or made up the difference between money raised and money needed, but not until about 1880 did they take over the bulk of the expenses for the fire departments. In Marshalltown, on the other hand, the city paid for virtually everything, from uniforms and badges to ladders and lanterns. ${ }^{25}$

Fire alarms and signaling systems contributed to the efficiency of fire protection services. It is not clear that any of the cities had alarm systems at the beginning of the 1870 s, other than the general hubbub that erupted when a fire did. But during the 1870 s and 1880 s all three installed various combinations of mechanical alarms, bells, and signaling systems.

In Marshalltown, for example, a city council committee recommended in 1874 that church bells be rung when fire broke out. After the waterworks was built in 1876, the city constructed an elaborate "telegraphic communication" system between the waterworks plant and the city-owned fire houses that enabled firemen to quickly signal the plant to raise the water pressure when fire broke out. Over the next few years the council added several mechanical alarm boxes, locating them throughout the city and wiring them to the "telegraphic" system. This addition to the fire-fighting service connected the fire fighters and their equipment to the waterworks system, thus making a unified whole of various municipal parts, and enveloping the entire city in the fire system's net. ${ }^{26}$

25. There are dozens of listings for fire department expenditures, many of which have already been listed in earlier footnotes. For fund-raising efforts such as dances and plays, see for Iowa City, Iowa City Republican, 1 December $1881,18,19$ October 1882, 2, 3, 15 February 1887. For Boone, see Boone County Republican, 15 May 1878. For descriptions of "subscriptions," see Minutes-Boone, 16 December 1874, 19, 26 December 1877, 28 January 1880. Ditzel's Fire Engines, Firefighters is a good source, in both pictures and text, for more information on the kinds of uniforms and small equipment used by nineteenth-century fire fighters, as is Kenneth Holcomb Dunshee, Enjine! Enjine!: A Story of Fire Protection (New York, 1939).

26. See Minutes-Marshalltown, 23 March 1874, 23 October 1876, 3 June 1878. See also ibid., 17 March 1879, for a mayor's report to the council and a description of the existing alarm apparatus. 
Iowa City, too, used a church bell during the 1870s. Fire fighters attached a "hammer" to the bell in a Baptist church and ran wires from the bell to a nearby engine company's house. In 1881 the council installed a mechanical alarm in the mayor's office, because, as one newspaper commented, it was something "every well regulated city" needed. Several years later, after a city waterworks had been installed, the council ran both a telephone line and an electrical alarm from the city hall to the waterworks. As in Marshalltown, these instruments served to tie the fire service to the water service in an interconnected system of parts. By the end of the decade electrical alarm boxes dotted the city, and the fire chief had implemented a signal system. After dividing the city into eight sections, he assigned each section a special signal, based on a series of rings and pauses, similar to a telegraphic code. This enabled fire fighters to learn immediately which part of town needed their services, and therefore allowed them to arrive at fires more quickly. ${ }^{27}$

In the late 1870 s Boone fire fighters hung an alarm bell on the city hall, connecting it to the railroad roundhouse, where a cistern fed the city's one hydrant. A ringing alarm not only signaled the railroad manager to fill the hydrant, but also, claimed the firemen, allowed volunteers living in various parts of the city to gather more quickly. By the end of the decade the council had added a mechanical alarm with a seven-hundred-pound bell, and a signal system similar to Iowa City's went into effect in $1891 .^{28}$

Efficient fire protection manifested itself in other ways. As the departments expanded, each city gradually moved the responsibility for them away from city councils and into the hands of more-or-less full-time caretakers. These changes represented a real shift away from ad hoc and toward permanently organized management. By the middle 1870s, for example, each council had a standing fire committee. Prior to the formation of these permanent committees, councils had acted through special committees as need dictated. Obviously the

27. Minutes-Iowa City, 5 December 1873; Iowa City Republican, 11 July 1881, 12 February, 22 June, 25, 28 July 1883, 15 October 1886.

28. Boone County Republican, 11 August 1875, 15 July 1891; MinutesBoone, 3 October 1878, 7, 28 January 1880. 
composition of the committees changed as new members were seated on the council, but using one specialized committee enabled lawmakers to deal with matters more efficiently than if it continued to use temporary ones. The committees increasingly relied on the work, advice, and expertise of outsiders. Committee members often consulted with other cities or wrote to several manufacturers for information before making major decisions. By the middle 1880 s all three cities had hired full-time caretakers for at least one of their firehouses. The caretaker often was required to live and sleep at the station. His duties included drying and oiling the hose; keeping all trucks, equipment, and buildings in good working order; and caring for horses or steam engines when they were used. ${ }^{29}$

On a day-to-day basis, however, the fire chief was the person upon whom council and townspeople depended for running the department. Once a fire department ordinance had been passed, each city council gradually relegated the bulk of the responsibility for departmental management to the chief. He informed the council fire committee what new equipment was needed, and almost without exception the councils approved his requests for money. The councils charged him with the responsibility for purchasing land and buildings for the firemen's use, maintaining adequate water supplies (prior to the construction of waterworks), and supervising all repairs and additions to the firehouses. Chiefs in all three cities also routinely took bids for new cisterns, arranged the contracts, and supervised their construction. Although chiefs were chosen by members of the fire companies and approved by the city council, there was little politicking involved in the job. It was not unusual for the same person to hold the post for five or more consecutive years. Indeed, in Boone the same man served as chief for almost twenty years. His initial selection was looked on with great favor, since, as one newspaper noted, he had held

29. Iowa City Daily Press, 31 May 1873, 9 August 1874, 8 October 1881; Minutes-Boone, 17 August 1870, 29 March 1871, 16 September 1874, 15 March 1875, 4 January 1882; Minutes-Marshalltown, 10 October 1870, 19 June 1871, 23 March 1874, 16 July 1877; Iowa City Republican, 4 January 1883. 
a similar post in an "eastern city" and therefore brought experience to the job. ${ }^{30}$

One other group completed the package of fire services available in Marshalltown and Iowa City: the fire police. Wearing their own special uniforms and badges, the group's main job was crowd control, another indication of the way perceptions about fire fighting had changed in just a few short years. Although Marshalltown enjoyed the services of a council-appointed fire police by the early 1870 s, Iowa City had no such group until a decade later. After the latter city built a waterworks, the fire department petitioned the city council for permission to dissolve one engine company and reorganize it as a fire police company. The job of the fire police, noted the petition, would be to keep back "the crowd which usually hinders the work of the firemen." Not all council members were convinced of the wisdom of the move. Some of them feared that the power to arrest would make the new police "head-strong and tyrannical." But municipal lawmakers passed the ordinance, thus taking what one newspaper called a "long step towards a perfectly organized fire department" by helping protect the fire fighters from "well-meaning but ignorant outsiders." A few months later another newspaper report commented on the efficiency and usefulness of the fire police, especially with their new rope that enabled them to barricade the fire site and keep back the crowd. ${ }^{31}$

30. From the available evidence, it appears that Iowa City and Marshalltown, which routinely spent thousands of dollars on their fire departments, did not pay their fire chiefs until sometime in the 1890 s, although Boone began paying its chief in the early 1880 s. For a sampling of the chiefs' activities, see Minutes-Marshalltown, 8 May 1871, 21 October 1872, 23 March 1874, 9 April 1877. See also Marshalltown's fire chief reports in Mayor's Address and Reports of City Officers, 1880; Financial Statement of the City of Marshalltown, Mayor's Address, Annual Report of the City Officers, 1881; ibid., 1882. For Boone, see Minutes-Boone, 22 August, 19 December 1877, 6 February, 15 May 1878,4 January 1882 . For the appointment and salary of the chief, see Boone County Republican, 25 July 1877; Minutes-Boone, 6 June 1883, 19 June 1888. For lowa City, see Iowa City Republican, 6 November 1883, 8 February, 5 April, 16 October 1886.

31. Marshalltown's fire department ordinance listed fire police as part of the department, but unlike regular fire fighters, the police were elected by the city council. However, in the late eighties the city passed an ordinance making the force a permanent one, no longer subject to the whims of the council members who had previously chosen them. See Minutes-Marshalltown, 28 
IN JUST A FEW YEARS a significant shift had occurred in what the residents of these cities considered adequate fire fighting. The path to a "perfectly organized" fire department lay in creating a specific institution, separate and differentiated from other aspects of city life and municipal government, designed to accomplish the important goal of putting out fires. Prior to the 1870s, when a fire erupted, anyone was believed capable of fighting it. During the 1870 s and 1880 s, however, these urbanites assigned the job of fire fighting to specially designated people. Residents organized fire companies that took over the task of actually combating flames, eliminating the bucket brigade and leaving other townspeople to watch from the sidelines. In the struggle against fire, the fire fighters relied on various types of hardware and equipment, such as carts, ladders, hoses, and pressurized water, as well as smaller pieces of gear such as rubber coats and hats, hydrant wrenches, and ropes to hold back crowds of onlookers. They wore badges and uniforms that distinguished them from the mayor and the marshall, for example, and from bystanders who showed up to watch the proceedings. This combination of specialized tools and companies working together in a single department was, townspeople believed, more productive and efficient than earlier efforts, when residents worked together in a temporarily organized bucket brigade and then dispersed when it was over. Just as an earlier era had deemed the bucket brigade efficient, and thus used it, so, too, these Iowans viewed the method developed in the $1870 \mathrm{~s}$ as a model of efficiency.

It is not clear exactly why this shift toward an emphasis on efficiency and system occurred, but an understanding of the experience of these three cities makes it possible to eliminate some otherwise plausible causes. Although each city suffered the effects of at least one major fire during this period, those fires alone did not provide the impetus for the drive to equip fire fighters. Each municipality had been visited by fire prior to the 1870 s, and yet citizens had considered the bucket brigade a sufficient tool to combat the flames. Nor was the great Chicago fire the cause of the drive to expand fire service in the 1870 s,

July 1873, 24 March, 14 April 1879, 15 April 1889. For Iowa City, see Iowa City Republican, 28 July 6, 10 November 1883, 23 February 1884. 
since the residents of each municipality had already begun to discuss and move toward increased fire protection well before that fire.

The cities' populations increased during the period, but the drive toward efficiency cannot be charged to urban congestion. True, the fire protection developed during the 1870 s extended mainly to the city centers, to the "business section," where buildings were crowded together, but after 1868 new buildings were generally built of fireproof materials rather than of wood. In addition, each city increased the number of fire fighters and available equipment, so that by 1890 there were companies, firehouses, and alarm mechanisms in every section of each city, including the "residence areas" where individual houses sat apart from one another rather than being packed tightly as in the business district.

Nor can the shift in the way these Iowans fought fires be charged to greater municipal powers, since the legal parameters within which the three cities operated scarcely changed between 1870 and 1890 . The argument that Boone and Marshalltown were merely taking advantage of their new secondclass powers carries little weight for two reasons. First, by the time those two gained that status, Iowa City was already about fifteen years old and much larger than the others, and yet had done nothing to systematize its fire-fighting service. Second, Iowa City's city council had passed a department ordinance prior to the Civil War but had never used it. Taken together, these two facts suggest that more was at work than increased municipal authority. In fact, the only major change in state law regarding fire protection in second-class cities came in 1890 when the legislature passed a bill permitting cities to levy a one-mill tax "for the purpose of maintaining a Fire Department." The law authorized city councils to pay fire fighters for the time they actually spent at a fire. ${ }^{32}$

It may be, then; that Iowans in these cities were simply motivated by a desire to effect some sort of regularity and system in their cities, in contrast to the morass of mismanagement that troubled the nation's largest cities during these years. That

32. 1890 Iowa Acts, 17. 
conclusion must be regarded as tentative, since a fire-fighting service is but one aspect of urban life. A more definitive conclusion awaits more solid evidence. One thing is certain: these Iowans established fire departments for reasons quite different than those usually cited for the emergence of "modern" fire fighting. 
Copyright of Annals of Iowa is the property of State of Iowa, by \& through the State Historical Society of Iowa and its content may not be copied or emailed to multiple sites or posted to a listserv without the copyright holder's express written permission. However, users may print, download, or email articles for individual use. 